\title{
Dietary vitamin D supplementation attenuates immune responses of pigs challenged with rotavirus potentially through the retinoic acid-inducible gene I signalling pathway
}

\author{
Ye Zhao ${ }^{1,2}$, Bing $\mathrm{Yu}^{1,2}$, Xiangbing Mao ${ }^{1,2}$, Jun $\mathrm{He}^{1,2}$, Zhiqing Huang ${ }^{1,2}$, Ping Zheng ${ }^{1,2}$, Jie Yu ${ }^{1,2}$, \\ Guoquan $\operatorname{Han}^{1,2}$, Xiaofang Liang ${ }^{1,2}$ and Daiwen Chen ${ }^{1,2_{*}}$ \\ ${ }^{1}$ Institute of Animal Nutrition, Sichuan Agricultural University, Xinkang Road 46\#, Ya'an Sichuan Province 625014, \\ People's Republic of China \\ ${ }^{2}$ Key Laboratory for Animal Disease-Resistance Nutrition of China Ministry of Education, Sichuan Agricultural University, \\ Ya'an, Sichuan 625014, People's Republic of China
}

(Submitted 23 September 2013 - Final revision received 17 February 2014 - Accepted 31 March 2014 - First published online 15 May 2014)

\section{Abstract}

In the present study, twenty-four Duroc $\times$ Landrance $\times$ Yorkshire (initial body weight (BW) of $21 \cdot 82$ (SEM 2.06) $\mathrm{kg}$ ) cross-bred pigs were used to determine whether dietary vitamin D supplementation could confer protection against viral infections through the retinoic acidinducible gene I (RIG-I) signalling pathway in pigs. Experimental treatments were arranged in a $2 \times 2$ factorial manner with the main effects of immune challenge (control $v$. porcine rotavirus (PRV) challenge) and dietary concentrations of vitamin D (200 and $5000 \mathrm{IU}$; where $1 \mathrm{IU}$ of vitamin D is defined as the biological activity of $0.025 \mathrm{mg}$ of cholecalciferol). The pigs were fed a diet containing 200 or 5000 IU vitamin D in the first week of the study period. On day 8, the pigs were orally dosed with $4 \mathrm{ml}$ of Dulbecco's modified Eagle's medium/Ham's F-12 medium containing PRV or essential medium (control). Serum samples were collected on day 8 (pre-challenge), and $6 \mathrm{~d}$ after the PRV challenge, the pigs were killed to evaluate intestinal morphology and tissue gene expression following the last blood collection. Pigs challenged with PRV had decreased BW gain $(P<0 \cdot 01)$, feed intake $(P<0 \cdot 01)$, villus height $(P<0 \cdot 01)$, faecal consistency $(P<0.05)$, and serum 1,25-dihydroxyvitamin $\mathrm{D}$ concentration $(P<0.01)$ and increased $(P<0.01)$ serum IL-2, IL- 6 and interferon (IFN)$\beta$ concentrations. Vitamin D supplementation mitigated these effects. The mRNA expression of RIG-I $(P<0 \cdot 01)$, IFN- $\beta$ promoter stimulator 1 $(P<0.01), \operatorname{IFN}-\beta(P<0.01)$ and interferon-stimulated gene $15\left(I S G_{15}\right)(P<0.01)$ was up-regulated by the PRV challenge and vitamin $\mathrm{D}$ supplementation in the intestine. In conclusion, vitamin D supplementation could activate the RIG-I signalling pathway and thus alleviate the negative effects caused by PRV challenge.

Key words: Vitamin D: Rotavirus: Pigs: Retinoic acid-inducible gene I signalling

The innate immune system is the first line of defence against invading pathogens. Innate immune responses are initiated by pattern recognition receptors, which recognise specific structures expressed by micro-organisms ${ }^{(1-3)}$. Retinoic acidinducible gene I (RIG-I), a type of pattern recognition receptor, plays a vital role in cytoplasmic viral double-stranded RNA recognition and innate immunity and in bridging innate and adaptive immune responses ${ }^{(4,5)}$. Upon recognition, RIG-I triggers signals through interferon- $\beta$ promoter stimulator 1 (IPS-1, also termed MAVS/VISA/Cardif), which results in the activation of host transcription factors, including $\mathrm{NF}-\kappa \mathrm{B}$ and interferon regulatory factor 3 , that orchestrate an early interferon (IFN)-independent transcriptional programme ${ }^{(6-8)}$.
Innate immune responses to viral infections are critically dependent on the successful production of type I IFN ${ }^{(9)}$.

Vitamin D belongs to the steroid hormone family. Vitamin D has two major forms, 25-hydroxyvitamin D and 1,25-dihydroxyvitamin D3 $\left(1,25(\mathrm{OH})_{2} \mathrm{D} 3\right)$. The major storage form of vitamin $\mathrm{D}$ is 25 -hydroxyvitamin $\mathrm{D}$, which is converted by the enzyme $1 \alpha$-hydroxylase (CYP27B1, cytochrome P450, family 27 , subfamily $\mathrm{B}$, polypeptide 1 ) to the main active metabolite $1,25(\mathrm{OH})_{2} \mathrm{D} 3^{(10)}$. Vitamin $\mathrm{D}$ has conventionally been associated with bone mineralisation and Ca homeostasis. New evidence from epidemiological studies reveals that it also plays an important role in the regulation of the immune system, including immune responses to viral infections. Vitamin D

Abbreviations: 1,25(OH) 2 D3, 1,25-dihydroxyvitamin D3; ADFI, average daily feed intake; CYP27B1, cytochrome P450, family 27, subfamily B, polypeptide 1; IFN, interferon; IPS-1, interferon- $\beta$ promoter stimulator 1 ; ISG ${ }_{15}$, interferon stimulated gene 15 ; PRV, porcine rotavirus; RIG-I, retinoic acid-inducible gene I; TCID $_{50}$, tissue culture infective dose 50; TLR, Toll-like receptor.

*Corresponding author: Professor D. Chen, fax +868352882088, email dwchen@sicau.edu.cn 
On day 8 of the dietary treatments, the challenged pigs were orally dosed with $4 \mathrm{ml}\left(105.8 \mathrm{TCID}_{50} / 100 \mu \mathrm{l}\right)$ of rotavirus OSU strain and the unchallenged pigs with $4 \mathrm{ml}$ of essential medium. The pigs were checked daily to evaluate their status after rotavirus challenge. Clinical signs (i.e. dehydration, apathy and diarrhoea) were monitored daily. Faecal consistency was recorded each morning at 08.00 hours by visual appraisal of each sample using a four-point scoring system and scored as follows: 0, solid; 1, semi-solid; 2, semi-liquid; 3 , liquid. Infection was defined as the excretion of rotavirus in the faeces with or without the development of clinical symptoms, usually diarrhoea.

Blood samples were collected in the morning of days 8 and 14 and were centrifuged at $3000 \mathrm{~g}$ for $10 \mathrm{~min}$. The isolated serum samples were stored at $-20^{\circ} \mathrm{C}$ until analysis. On day 14 , all the pigs were killed with an intracardiac injection of sodium pentobarbital $(150 \mathrm{mg} / \mathrm{kg})$. The abdomen was immediately opened. The intestinal sections were identified according to the method of Wang et al. ${ }^{(23)}$. The mid-jejunum was isolated for histological analysis. The duodenum, jejunum and ileum were removed, flushed with ice-cold saline and then snap-frozen in liquid $\mathrm{N}_{2}$ for further analysis.

\section{Cytokine assays}

The serum concentrations of IL-2, IL- 6 and IFN- $\beta$ were determined using commercially available swine ELISA kits ( $\& D$ Systems China Company Limited) according to the manufacturer's instructions. The detection limits of these ELISA were as follows: IL-2, $8 \mathrm{pg} / \mathrm{ml}$; IL- $6,8 \mathrm{pg} / \mathrm{ml}$; IFN- $\beta, 20 \mathrm{pg} / \mathrm{ml}$. The serum concentration of $1,25(\mathrm{OH})_{2} \mathrm{D} 3$ was determined by ELISA (Immunodiagnostic Systems, Inc.). All the assays were run in duplicate using a plate reader.

\section{Total RNA extraction and reverse transcription reaction}

Total RNA was isolated using the TRIzol reagent (Invitrogen) according to the manufacturer's instructions. The concentrations of total RNA were determined spectrophotometrically using a Beckman Coulter DU 800 (Beckman Coulter). The integrity of the RNA was verified by agarose gel electrophoresis. From each sample, $1 \mu \mathrm{g}$ of total RNA was reverse-transcribed in a final volume of $20 \mu \mathrm{l}$ using the PrimeScript ${ }^{\circledR}$ RT Reagent Kit with gDNA Eraser (TaKaRa) according to the manufacturer's protocol. RT products (complementary DNA) were stored at $-70^{\circ} \mathrm{C}$.

\section{Real-time quantitative PCR}

Real-time quantitative PCR were carried out using the CFX96 Real-Time PCR Detection System (Bio-Rad). The gene-specific primers used in the present study are listed in Table 2 . The PCR mixture consisted of $1 \mu$ l of the first-strand complementary DNA sample, $0.5 \mu \mathrm{l}$ of each of the forward and reverse primers from $10 \mu \mathrm{m}$ stocks, $3 \mu \mathrm{l}$ of diethylpyrocarbonate-treated water and $5 \mu$ l of $2 \times$ SsoFast EvaGreen Supermix (Bio-Rad). Cycling conditions were as follows: $98^{\circ} \mathrm{C}$ for $10 \mathrm{~s}$, followed by forty cycles of $98^{\circ} \mathrm{C}$ for $5 \mathrm{~s}$, annealing at temperatures given in Table 2 for $10 \mathrm{~s}$ and $72^{\circ} \mathrm{C}$ for $15 \mathrm{~s}$. A melting curve analysis was carried out after each real-time quantitative PCR to check and verify the specificity and purity of all PCR products. Each sample was amplified in triplicate. A standard curve was constructed using serial dilutions of one of the complementary DNA samples. The standard curve was drawn by plotting the natural log of the threshold cycle $\left(C_{t}\right)$ against the natural $\log$ of the number of molecules. The $C_{t}$ was defined as the cycle at which a statistically significant increase in the magnitude of the signal generated by the PCR was first detected. The standard curve of each gene was generated in duplicate and three times for obtaining reliable amplification efficiency values. The correlation coefficients $\left(r^{2}\right)$ of all the standard curves were $>0.99$ and the amplification efficiency values ranged between 90 and $110 \%$. The mRNA concentration of the target gene was normalised to that of the reference gene $\beta$-actin.

Table 2. Primers and annealing temperatures used in real-time quantitative PCR

\begin{tabular}{|c|c|c|c|c|}
\hline Primer names & Sequence $\left(5^{\prime}-3^{\prime}\right)$ & Product size (bp) & Annealing temperature $\left({ }^{\circ} \mathrm{C}\right)$ & GenBank ID \\
\hline$R I G-I-Q F$ & CCTCGGTGGCAGATGAAG & 148 & $59 \cdot 0$ & EU126659 \\
\hline$R I G-I-Q R$ & TCAGCGTTAGCAGTCAGAAG & & & \\
\hline$T L R 3-Q F$ & CTCGCTGATTCTCCTCTTCTC & 150 & $59 \cdot 0$ & NM_001097444 \\
\hline$T L R 3-Q R$ & TCTCCATTCСTGTCCTGTGA & & & \\
\hline IPS-1-QF & AGAAGCAGGACACAGAAC & 95 & $59 \cdot 0$ & JN644269 \\
\hline$I P S-1-Q R$ & GAAGGAGACAGTCGGAGA & & & \\
\hline$I S G_{15}-Q F$ & ACCATTTCTGGCTGACTTTC & 78 & $55 \cdot 8$ & EU584557 \\
\hline$I S G_{15}-Q R$ & ACATAGGCTTGAGGTCATACT & & & \\
\hline$I F N-\beta-Q F$ & AATCGCTCTCCTGATGTGTT & 81 & $59 \cdot 6$ & NM_001003923 \\
\hline IFN- $\beta-Q R$ & TTGCTGCTCCTTTGTTGGTA & & & \\
\hline$P R V-Q F$ & TCAGTTCGTCAGGAATATGC & 92 & 53.5 & AF317123 \\
\hline$P R V-Q R$ & CTTGAAGGTGAGTAGTTGGT & & & \\
\hline CYP27B1-QF & TGGTCAAGGAAGTGCTAAGA & 86 & $55 \cdot 8$ & DQ295065 \\
\hline$C Y P 27 B 1-Q R$ & AATGTAGTCACCCACACAAATG & & & \\
\hline$A C T-Q F$ & TCTGGCACCACACCTTCT & 97 & $59 \cdot 0$ & U07786 \\
\hline$A C T-Q R$ & TGATCTGGGTCATCTTCTCAC & & & \\
\hline
\end{tabular}

RIG-I, retinoic acid-inducible gene I; QF, quantitative forward primer; QR, quantitative reverse primer; TLR3, Toll-like receptor 3; IPS-1, interferon- $\beta$ promoter stimulator 1 ; ISG 15 , interferon-stimulated gene 15; IFN, interferon; PRV, porcine rotavirus; CYP27B1, cytochrome P450, family 27, subfamily $\mathrm{B}$, polypeptide $1 ; A C T$, actin. 


\section{Statistical analysis}

Data collected before the PRV challenge were analysed by one-way ANOVA using the general linear model procedure of the Statistical Analysis Package, SAS version 9.1 (SAS Institute, Inc.). Faecal consistency data were analysed as repeated measures using the MIXED procedure of SAS 9.1 according to the following model:

$$
\begin{aligned}
Y_{i j k l}= & \mu+\alpha_{i}+\beta_{j}+\left(\alpha \beta_{i j}\right)+U_{k}+\omega_{l}+(\alpha \omega)_{i l}+(\beta \omega)_{j l} \\
& +(\alpha \beta \omega)_{i j l}+\varepsilon_{i j k l},
\end{aligned}
$$

where $\mu$ is the mean, $\alpha_{i}$ is the effect of immune challenge ( $i=$ PRV or essential medium), $\beta_{j}$ is the effect of vitamin D ( $j=200$ or $5000 \mathrm{IU}$ ), $\alpha \beta_{i j}$ is the interaction between immune challenge and vitamin $\mathrm{D}, U_{k}$ is the pig $(k=1,2, \ldots, 24), \omega_{l}$ is the time (days $1,2, \ldots, 6), \alpha \omega_{i l}$ is the interaction between immune challenge and time, $\beta \omega_{j l}$ is the interaction between vitamin $\mathrm{D}$ and time, $\alpha \beta \omega_{i j l}$ is the interaction between immune challenge, vitamin $\mathrm{D}$ and time, and $\varepsilon_{i j k l}$ represents the random error. Growth performance, intestinal morphology, serum cytokine and gene expression data were analysed according to the model, but the effects of time and the interaction between time, immune challenge and vitamin $\mathrm{D}$ were omitted. When the effects of treatment were established $(P<0.05)$, treatment least-squares means were separated using the probability of difference function adjusted by the TukeyKramer test. Random effect was used to account for the variation between the pigs. Results are expressed as least-squares means with their standard errors. Probability values $<0.05$ were used as the criterion for statistical significance.

\section{Results}

\section{Growth performance}

During the pre-challenge periods, there were no significant differences in the average daily gain, average daily feed intake (ADFI) and feed:gain ratio of the pigs. Compared with the unchallenged pigs, the $200 \mathrm{IU}$ dietary vitamin D-supplemented pigs challenged with PRV had decreased average daily gain $(P<0.05)$ and ADFI $(P<0.05)$, whereas in the 5000 IU dietary vitamin D-supplemented pigs challenged with PRV, average daily gain and ADFI reduction was significantly alleviated (Table 3). The PRV challenge also led to a remarkable decrease in the feed:gain ratio $(P<0.01)$. However, there were no significant effects of dietary supplementation with $5000 \mathrm{IU}$ vitamin D on the feed:gain ratio. There was an interaction between dietary vitamin D levels and PRV challenge with regard to ADG and ADFI.

\section{Faecal consistency}

The effects of treatment on faecal consistency from day 8 to day 14 after the challenge are shown in Fig. 1. On day 6 after the challenge, the 200 IU dietary vitamin D-supplemented pigs challenged with PRV had reduced faecal consistency compared with the unchallenged pigs $(P<0 \cdot 05)$. Dietary supplementation with 5000 IU vitamin D improved the faecal consistency of the challenged pigs compared with dietary supplementation with $200 \mathrm{IU}$ vitamin D, but not to the same extent as that observed in the unchallenged pigs $(P<0 \cdot 05)$

\section{Histomorphology}

Compared with the unchallenged pigs, the 200 IU dietary vitamin D-supplemented pigs challenged with PRV had decreased villus height $(P<0.05)$ and crypt depth $(P<0.05)$ (Table 4$).$ Dietary supplementation with $5000 \mathrm{IU}$ vitamin D mitigated the challenge-induced damage to the intestinal epithelium $(P<0.05)$. There was an interaction between dietary vitamin $\mathrm{D}$ levels and PRV challenge with regard to villus height $(P<0 \cdot 01)$. No difference was found in the crypt depth and villi:crypt ratio in the mid-jejunum among the treatment groups.

\section{Serum IL-2, IL-6 and interferon- $\beta$ concentrations}

As shown in Fig. 2, the 200 IU dietary vitamin D-supplemented pigs challenged with PRV had significantly increased serum concentrations of IL-2 $(P<0 \cdot 01)$, IL-6 $(P<0 \cdot 01)$ and IFN- $\beta$ $(P<0.01)$ on day 14 compared with the unchallenged pigs.

Table 3. Effect of vitamin $D(V D)$ supplementation and porcine rotavirus (PRV) challenge on the growth performance of pigs*

\begin{tabular}{|c|c|c|c|c|c|c|c|c|}
\hline \multirow[b]{2}{*}{ Items } & \multicolumn{2}{|c|}{$\operatorname{PRV}(-)$} & \multicolumn{2}{|c|}{ PRV (+) } & \multirow[b]{2}{*}{ SEM } & \multicolumn{3}{|c|}{ Analysis by effect $(P)$} \\
\hline & $\begin{array}{c}\text { VD } \\
(200 I U)\end{array}$ & $\begin{array}{c}\text { VD } \\
\text { (5000 IU) }\end{array}$ & $\begin{array}{c}\text { VD } \\
(200 I U)\end{array}$ & $\begin{array}{c}\text { VD } \\
(5000 \mathrm{IU})\end{array}$ & & VD & PRV challenge & VD $\times$ PRV challenge \\
\hline \multicolumn{9}{|l|}{$A D G(g)$} \\
\hline Days 0-7 (pre-challenge) & 669.6 & $658 \cdot 8$ & - & - & $10 \cdot 3$ & 0.445 & - & - \\
\hline Days 8-14 (post-challenge) & $669 \cdot 4^{c}$ & $679 \cdot 2^{c}$ & $430 \cdot 6^{a}$ & $540 \cdot 3^{b}$ & $14 \cdot 0$ & $<0.01$ & $<0.01$ & $<0.01$ \\
\hline \multicolumn{9}{|l|}{$\operatorname{ADFI}(g)$} \\
\hline Days $0-7$ (pre-challenge) & $1365 \cdot 0$ & 1364.5 & - & - & $20 \cdot 0$ & 0.303 & - & - \\
\hline Days 8-14 (post-challenge) & $1350 \cdot 1^{\mathrm{c}}$ & $1398 \cdot 5^{c}$ & $1067 \cdot 5^{a}$ & $1251 \cdot 5^{\mathrm{b}}$ & $30 \cdot 1$ & $<0.01$ & $<0.01$ & 0.036 \\
\hline \multicolumn{9}{|l|}{ Feed:gain ratio } \\
\hline Days $0-7$ (pre-challenge) & 2.04 & 2.07 & - & - & 0.03 & 0.179 & - & - \\
\hline Days 8-14 (post-challenge) & $2 \cdot 02^{\mathrm{a}}$ & $2 \cdot 06^{\mathrm{a}}$ & $2 \cdot 49^{b}$ & $2 \cdot 32^{b}$ & 0.06 & 0.285 & $<0.01$ & 0.080 \\
\hline
\end{tabular}
(Mean values with their standard errors, $1-7 \mathrm{~d}(n 12) ; 8-14 \mathrm{~d}(n 6)$ )

$A D G$, average daily gain; ADFI, average daily feed intake.

a,b,c Mean values within a row with unlike superscript letters were significantly different $(P<0.05)$

* $1 \mathrm{IU}$ of vitamin D is defined as the biological activity of $0.025 \mathrm{mg}$ of cholecalciferol. 


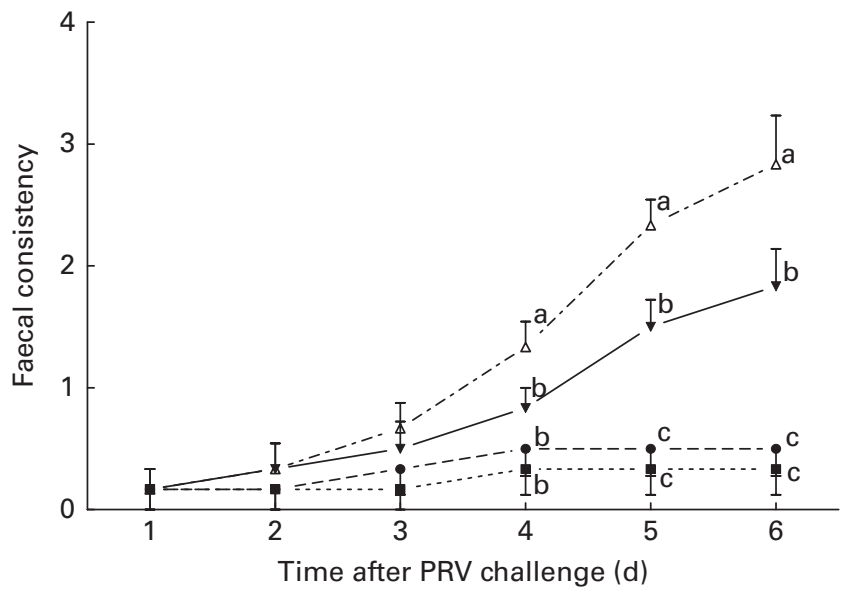

Fig. 1. Faecal consistency (experimental days 1-6) of pigs not challenged with PRV and fed a diet supplemented with $200 \mathrm{IU}$ vitamin D (NONV, - - ), pigs not challenged with PRV and fed a diet supplemented with $5000 \mathrm{IU}$ vitamin D (NOHV, - - ) , pigs orally dosed with porcine rotavirus (PRV) and fed a diet supplemented with $200 \mathrm{IU}$ vitamin D (CHNV, $\left.-\mathrm{A}_{-}\right)$, and pigs orally dosed with PRV and fed a diet supplemented with $5000 \mathrm{IU}$ vitamin $\mathrm{D}(\mathrm{CHHV}, \rightarrow-$ ); where $1 \mathrm{IU}$ of vitamin $\mathrm{D}$ is defined as the biological activity of $0.025 \mathrm{mg}$ of cholecalciferol. Values are means, with their standard errors represented by vertical bars. ${ }^{a, b, c}$ Mean values with unlike letters were significantly different within each day $(P<0.05)$.

Dietary supplementation with $5000 \mathrm{IU}$ vitamin D decreased the concentrations of IL-2 $(P<0 \cdot 01)$ and IL-6 $(P<0 \cdot 01)$, but significantly increased that of IFN- $\beta \quad(P<0 \cdot 01)$ compared with dietary supplementation with 200 IU vitamin D.

\section{Serum 1,25-dihydroxyvitamin $D$ concentration and} cytochrome P450, family 27, subfamily $B$, polypeptide 1 mRNA expression in the mid-jejunum

Data obtained for serum $1,25(\mathrm{OH})_{2} \mathrm{D} 3$ concentration and CYP27B1 mRNA expression in the mid-jejunum are shown in Fig. 3. Compared with the $200 \mathrm{IU}$ dietary vitamin D-supplemented pigs not challenged with PRV, the $200 \mathrm{IU}$ dietary vitamin D-supplemented pigs challenged with PRV had a reduced serum concentration of $1,25(\mathrm{OH})_{2} \mathrm{D} 3$ $(P<0 \cdot 01)$. Dietary supplementation with $5000 \mathrm{IU}$ vitamin D increased the serum concentration of $1,25(\mathrm{OH})_{2} \mathrm{D} 3$ $(P<0 \cdot 01)$. CYP27B1 is required for the conversion of 25-hydroxyvitamin $\mathrm{D}$ into $1,25(\mathrm{OH})_{2} \mathrm{D} 3$. The abundance of CYP27B1 mRNA in the mid-jejunum was enhanced after the PRV challenge $(P<0 \cdot 01)$. Dietary supplementation with
$5000 \mathrm{IU}$ vitamin D tended to increase the abundance of CYP27B1 mRNA in the mid-jejunum. Furthermore, there was a significant effect of vitamin $D$ level $\times$ PRV challenge interaction on the abundance of $C Y P 27 B 1$ mRNA in the mid-jejunum.

Expression of retinoic acid-inducible gene I, Toll-like receptor 3 , interferon- $\beta$ promoter stimulator 1 , interferon- $\beta$ and interferon-stimulated gene 15 in the intestine

Data obtained for the mRNA expression of RIG-I, Tolllike receptor (TLR)3, IPS-1,IFN- $\beta$ and $I S G_{15}$ are summarised in Table 5. Compared with the $200 \mathrm{IU}$ dietary vitamin Dsupplemented pigs not challenged with PRV, the $200 \mathrm{IU}$ dietary vitamin D-supplemented pigs challenged with PRV had an increased abundance of $R I G-I$ mRNA in the duodenum $(P<0.05)$, jejunum $(P<0.05)$ and ileum $(P<0 \cdot 05)$. Dietary supplementation with $5000 \mathrm{IU}$ vitamin D significantly increased the abundance of $R I G-I$ mRNA in the jejunum $(P<0.05)$ and ileum $(P<0.05)$ compared with dietary supplementation with $200 \mathrm{IU}$ vitamin D. There was a significant effect of vitamin D level $\times$ PRV challenge interaction on the mRNA expression of $R I G-I$ in the jejunum and ileum $(P<0 \cdot 01)$. No effects of treatment were observed on the mRNA expression of TLR3.

Compared with the 200 IU dietary vitamin D-supplemented pigs not challenged with PRV, the $200 \mathrm{IU}$ dietary vitamin Dsupplemented pigs challenged with PRV had an increased abundance of IPS-1 mRNA in the duodenum $(P<0.05)$, jejunum $(P<0.05)$ and ileum $(P<0.05)$. Dietary supplementation with $5000 \mathrm{IU}$ vitamin D significantly increased the abundance of $R I G-I$ mRNA in the duodenum $(P<0.05)$, jejunum $(P<0.05)$ and ileum $(P<0.05)$ compared with dietary supplementation with $200 \mathrm{IU}$ vitamin D. There was a significant effect of vitamin D level $\times$ PRV challenge interaction on the mRNA expression of IPS-1 in the jejunum $(P<0 \cdot 01)$.

After the PRV challenge, the mRNA expression of $I F N-\beta$ was increased in the duodenum $(P<0 \cdot 01)$, jejunum $(P<0 \cdot 01)$ and ileum $(P<0 \cdot 01)$. Compared with the $200 \mathrm{IU}$ dietary vitamin D-supplemented pigs challenged with PRV, the $5000 \mathrm{IU}$ dietary vitamin D-supplemented pigs challenged with PRV had an increased abundance of IPS-1 mRNA in the duodenum $(P<0.05)$, jejunum $(P<0.05)$ and ileum $(P<0 \cdot 05)$. There was a significant effect of vitamin $\mathrm{D}$

Table 4. Effect of vitamin D (VD) supplementation and porcine rotavirus (PRV) challenge on the villus height (VH; $\mu \mathrm{m})$, crypt depth (CD; $\mu \mathrm{m})$ and villi: crypt ratio (VCR) in the mid-jejunum of pigs ${ }^{*}$

(Mean values with their standard errors, $n 6$ )

\begin{tabular}{|c|c|c|c|c|c|c|c|c|}
\hline \multirow[b]{2}{*}{ Items } & \multicolumn{2}{|c|}{$\operatorname{PRV}(-)$} & \multicolumn{2}{|c|}{ PRV $(+)$} & \multirow[b]{2}{*}{ SEM } & \multicolumn{3}{|c|}{ Analysis by effect $(P)$} \\
\hline & VD (200IU) & VD (5000IU) & VD (200IU) & VD (5000IU) & & VD & PRV challenge & VD $\times$ PRV challenge \\
\hline $\mathrm{VH}$ & $482 \cdot 8^{\mathrm{b}}$ & $476 \cdot 4^{\mathrm{b}}$ & $391 \cdot 8^{\mathrm{a}}$ & $468 \cdot 1^{\mathrm{b}}$ & $13 \cdot 56$ & $<0.05$ & $<0.01$ & $<0.01$ \\
\hline$C D$ & $209 \cdot 7^{b}$ & $202 \cdot 0^{\mathrm{b}}$ & $176 \cdot 0^{a}$ & $206 \cdot 6^{\mathrm{b}}$ & 8.54 & 0.18 & 0.09 & 0.06 \\
\hline VCR & $2 \cdot 33$ & $2 \cdot 47$ & $2 \cdot 30$ & $2 \cdot 29$ & 0.13 & 0.58 & 0.45 & 0.33 \\
\hline
\end{tabular}

${ }^{\mathrm{a}, \mathrm{b}}$ Mean values within a row with unlike superscript letters were significantly different $(P<0.05)$

* $1 \mathrm{IU}$ of vitamin $\mathrm{D}$ is defined as the biological activity of $0.025 \mathrm{mg}$ of cholecalciferol. 

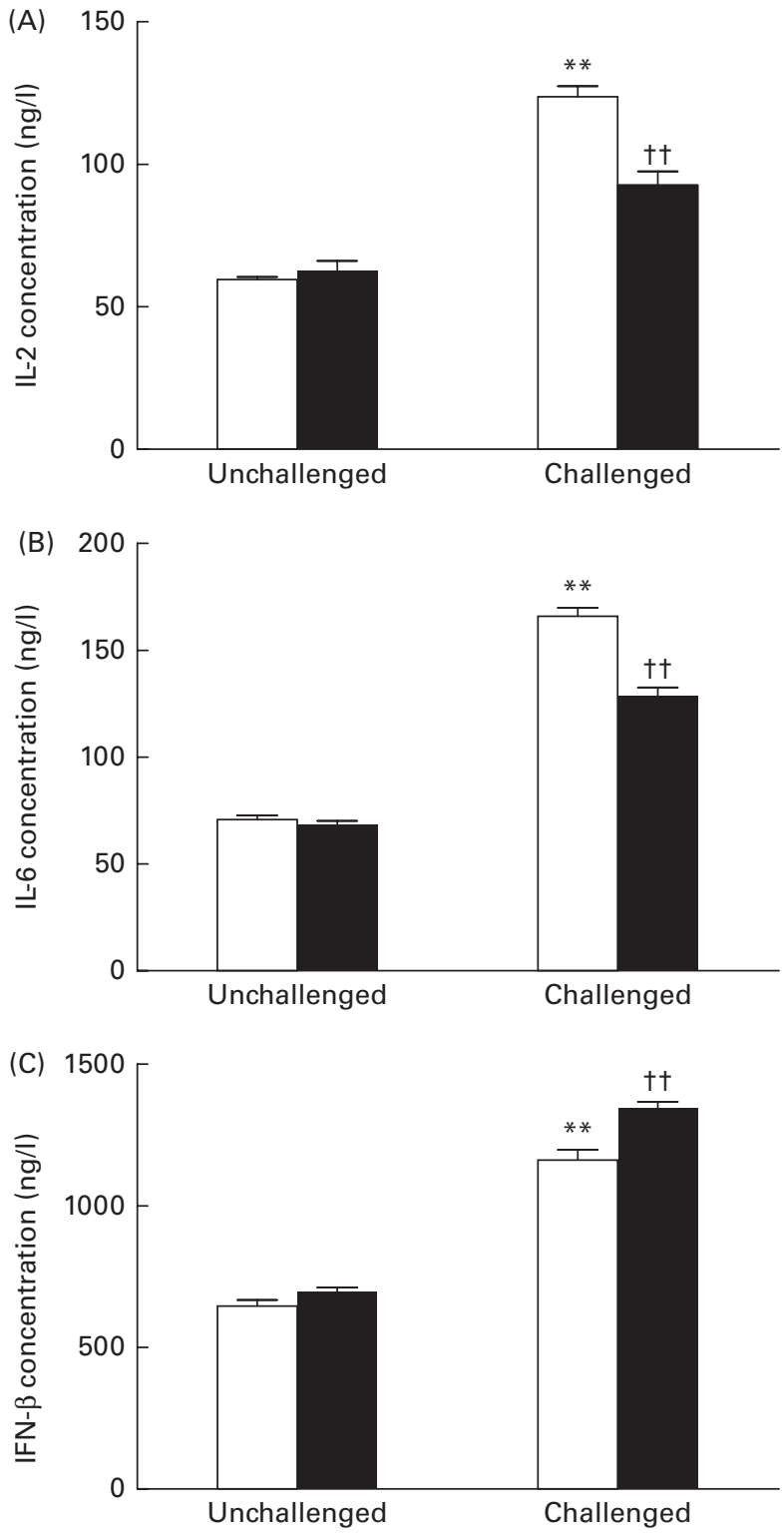

Fig. 2. Effect of vitamin $D$ on the serum concentrations of (A) IL-2, (B) IL-6 and $(C)$ interferon $-\beta$ (IFN- $\beta$ ) of pigs challenged or not challenged with porcine rotavirus. $\square, 200 \mathrm{IU}$ vitamin D; $\mathbf{\square}, 5000 \mathrm{IU}$ vitamin D; where $1 \mathrm{IU}$ of vitamin D is defined as the biological activity of $0.025 \mathrm{mg}$ of cholecalciferol. Values are means, with their standard errors represented by vertical bars. ${ }^{\star \star}$ Mean value was significantly different from that of the $200 \mathrm{IU}$ vitamin D-supplemented group not challenged with PRV $(P<0.01)$. †† Mean value was significantly different from that of the $200 \mathrm{IU}$ vitamin $\mathrm{D}$-supplemented group challenged with PRV $(P<0.01)$.

level $\times$ PRV challenge interaction on the mRNA expression of $I F N-\beta$ in the duodenum $(P<0.01)$ and jejunum $(P<0.05)$.

The abundance of $I S G_{15}$ mRNA in the duodenum, jejunum, and ileum $(P<0 \cdot 01)$ was enhanced after the PRV challenge. Compared with the $200 \mathrm{IU}$ dietary vitamin D-supplemented pigs challenged with PRV, the $5000 \mathrm{IU}$ dietary vitamin Dsupplemented pigs challenged with PRV had an increased abundance of IPS-1 mRNA in the jejunum $(P<0.05)$ and ileum $(P<0.05)$. There was no effect of vitamin $\mathrm{D}$ level $\times \mathrm{PRV}$ challenge interaction.

\section{Discussion}

Rotavirus is a major pathogen causing symptomatic gastroenteritis in infants and young children, as well as in other young animals ${ }^{(24,25)}$. The PRV used in the present experiment was a tissue culture-adapted OSU strain (ATCC \#VR-893), which was passaged in IPEC-J2 cells. In the present study, we first used in vivo methods to elucidate the early interferon response to rotavirus infection and the effect of vitamin D on host-pathogen interactions.

The results of the present experiment were consistent with previous observations showing that PRV challenge caused a reduction in villus height, an increase in cytokine concentrations and finally a decrease in growth performance ${ }^{(26-28)}$. Rotavirus replicates in the enterocytes of the small intestine, inducing villous atrophy and malabsorptive diarrhoea ${ }^{(26)}$. Cytokines such as IL- 6 are important markers of the progress of rotavirus infection in children ${ }^{(29)}$. In the present experiment, the serum concentration of IL- 6 was significantly
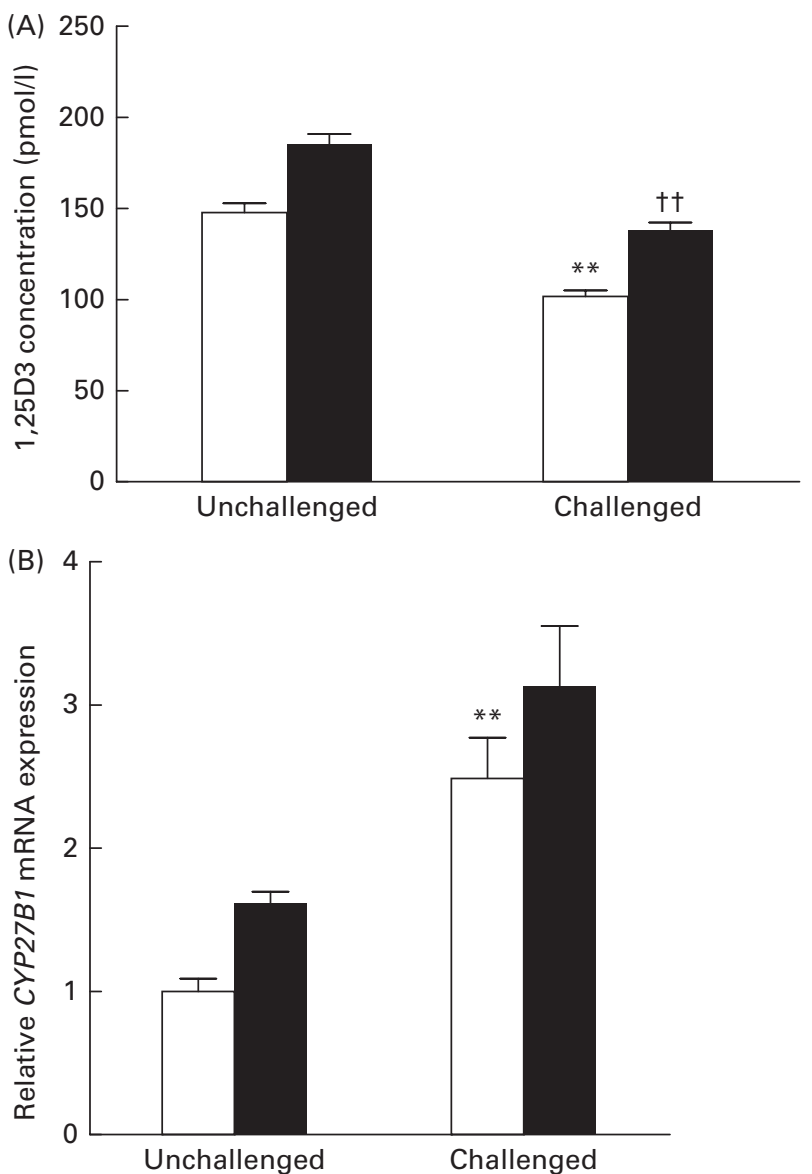

Fig. 3. Effect of vitamin $D$ on the (A) serum 1,25-dihydroxyvitamin $D$ $\left(1,25(\mathrm{OH})_{2} \mathrm{D} 3\right)$ concentration and $(B)$ cytochrome $\mathrm{P} 450$, family 27 , subfamily $\mathrm{B}$, polypeptide 1 (CYP27B1) mRNA expression of pigs challenged or not challenged with porcine rotavirus. $\square, 200 \mathrm{IU}$ vitamin D;, $5000 \mathrm{IU}$ vitamin D; where $1 \mathrm{IU}$ of vitamin D is defined as the biological activity of $0.025 \mathrm{mg}$ of cholecalciferol. Values are means, with their standard errors represented by vertical bars. ${ }^{* *}$ Mean value was significantly different from that of the $200 \mathrm{IU}$ vitamin D-supplemented group not challenged with PRV $(P<0.01)$. †† Mean value was significantly different from that of the $200 \mathrm{IU}$ vitamin D-supplemented group challenged with PRV $(P<0.01)$. 
Table 5. Effect of vitamin $D(V D)$ supplementation and porcine rotavirus (PRV) challenge on the relative expression of retinoic acid-inducible gene I (RIG-I), Toll-like receptor (TLR3), interferon- $\beta$ promoter stimulator 1 (IPS-1), interferon- $\beta$ (IFN- $\beta$ ) and interferon-stimulated gene 15 (ISG 15$)$ mRNA in the intestine of pigs $\dagger$

(Mean values with their standard errors, $\mathrm{n} 6$ )

\begin{tabular}{|c|c|c|c|c|c|c|c|c|}
\hline \multirow[b]{2}{*}{ Items } & \multicolumn{2}{|c|}{$\operatorname{PRV}(-)$} & \multicolumn{2}{|c|}{$\operatorname{PRV}(+)$} & \multirow[b]{2}{*}{ SEM } & \multicolumn{3}{|c|}{$P$} \\
\hline & VD (200IU) & VD (5000 IU) & VD (200IU) & VD (5000 IU) & & VD & PRV challenge & VD $\times$ PRV challenge \\
\hline \multicolumn{9}{|l|}{ RIG-I } \\
\hline Duodenum & $1.00^{\mathrm{a}}$ & $1.40^{\mathrm{b}}$ & $1.55^{\mathrm{b}, \mathrm{c}}$ & $1.69^{c}$ & 0.08 & $<0.01$ & $<0.01$ & 0.09 \\
\hline Jejunum & $1.00^{\mathrm{a}}$ & $1 \cdot 13^{\mathrm{a}}$ & $2 \cdot 50^{\mathrm{b}}$ & $3.47^{\mathrm{C}}$ & 0.09 & $<0.01$ & $<0.01$ & $<0.01$ \\
\hline Ileum & $1.00^{\mathrm{a}}$ & $1 \cdot 23^{a}$ & $3 \cdot 16^{\mathrm{b}}$ & $4 \cdot 10^{C}$ & 0.09 & $<0.01$ & $<0.01$ & $<0.01$ \\
\hline \multicolumn{9}{|l|}{ TLR3 } \\
\hline Duodenum & 1.00 & 1.30 & 1.13 & 1.24 & 0.13 & 0.31 & 0.62 & 0.22 \\
\hline Jejunum & 1.00 & $1 \cdot 18$ & 1.24 & 1.37 & 0.22 & 0.47 & 0.36 & 0.19 \\
\hline Ileum & 1.00 & 0.91 & 1.08 & 1.03 & 0.10 & 0.51 & 0.35 & 0.83 \\
\hline \multicolumn{9}{|l|}{ IPS-1 } \\
\hline Duodenum & $1.00^{\mathrm{a}}$ & $1 \cdot 20^{\mathrm{a}}$ & $1.55^{\mathrm{b}}$ & $1.99^{\mathrm{C}}$ & 0.09 & $<0.01$ & $<0.01$ & 0.17 \\
\hline Jejunum & $1.00^{\mathrm{a}}$ & $1 \cdot 16^{\mathrm{a}}$ & $2 \cdot 18^{\mathrm{b}}$ & $3.41^{\mathrm{c}}$ & 0.10 & $<0.01$ & $<0.01$ & $<0.01$ \\
\hline lleum & $1.00^{\mathrm{a}}$ & $1.02^{\mathrm{a}}$ & $2 \cdot 35^{\mathrm{b}}$ & $2 \cdot 84^{c}$ & 0.12 & $<0.05$ & $<0.01$ & 0.07 \\
\hline \multicolumn{9}{|l|}{ IFN- $\beta$} \\
\hline Duodenum & $1.00^{\mathrm{a}}$ & $1 \cdot 20^{\mathrm{a}}$ & $1.92^{\mathrm{b}}$ & $3 \cdot 36^{c}$ & 0.13 & $<0.01$ & $<0.01$ & $<0.01$ \\
\hline Jejunum & $1.00^{\mathrm{a}}$ & $1.07^{\mathrm{a}}$ & $2 \cdot 37^{\mathrm{b}}$ & $3 \cdot 24^{\mathrm{C}}$ & 0.17 & $<0.01$ & $<0.01$ & $<0.05$ \\
\hline lleum & $1.00^{\mathrm{a}}$ & $1.06^{\mathrm{a}}$ & $2 \cdot 77^{\mathrm{b}}$ & $3 \cdot 31^{\mathrm{c}}$ & 0.16 & 0.07 & $<0.01$ & 0.14 \\
\hline \multicolumn{9}{|l|}{$I S G_{15}$} \\
\hline Duodenum & $1.00^{\mathrm{a}}$ & $1.05^{\mathrm{a}}$ & $2 \cdot 32^{\mathrm{b}}$ & $2 \cdot 58^{\mathrm{b}}$ & 0.10 & 0.12 & $<0.01$ & 0.30 \\
\hline Jejunum & $1.00^{\mathrm{a}}$ & $1 \cdot 20^{\mathrm{a}}$ & $2 \cdot 77^{\mathrm{b}}$ & $3.40^{\mathrm{C}}$ & 0.14 & $<0.01$ & $<0.01$ & 0.13 \\
\hline Ileum & $1.00^{\mathrm{a}}$ & $1.22^{\mathrm{a}}$ & $2 \cdot 10^{\mathrm{b}}$ & $2 \cdot 64^{\mathrm{C}}$ & 0.13 & $<0.01$ & $<0.01$ & 0.21 \\
\hline
\end{tabular}

a,b,c Mean values within a row with unlike superscript letters were significantly different $(P<0.05)$.

${ }^{*}$ Tissues were collected in the morning of day 14.

$\dagger 1 \mathrm{IU}$ of vitamin $\mathrm{D}$ is defined as the biological activity of $0.025 \mathrm{mg}$ of cholecalciferol.

increased after the PRV challenge, while faecal consistency was significantly decreased. This result indicates that the PRV challenge model is useful for studying vitamin Dmediated innate antiviral immune responses.

Vitamin D is a steroid hormone that has long been known for its role in mineral metabolism and bone growth. The main active vitamin $\mathrm{D}\left(1,25(\mathrm{OH})_{2} \mathrm{D} 3\right)$ is thought to be a key component of non-classical vitamin $\mathrm{D}$ functions. In the present study, dietary vitamin $\mathrm{D}$ supplementation was found to increase serum $1,25(\mathrm{OH})_{2} \mathrm{D} 3$ concentration, while the PRV challenge was found to significantly decrease it, indicating that more amounts of $1,25(\mathrm{OH})_{2} \mathrm{D} 3$ are required to confer protection against viral infections in pigs. Apart from playing a role in bone mineralisation and $\mathrm{Ca}$ homeostasis, vitamin $\mathrm{D}$ also modulates the adaptive immune system by exerting direct effects on the activation of $\mathrm{T}$ cells and the phenotype and function of antigen-presenting cells, particularly of dendritic cells ${ }^{(30)}$. In addition, vitamin $\mathrm{D}$ also plays an important role in the regulation of the immune system, including immune responses to viral infections ${ }^{(11,12,13)}$. Due to the functions of vitamin $\mathrm{D}$, it is easy to understand why pigs need more amounts of vitamin $\mathrm{D}$ under immune challenge conditions. The enzyme CYP27B1 is the key determinant in the synthesis of active vitamin D. This enzyme was first detected in the kidneys, where it has been found to be highly expressed. Extrarenal CYP27B1 has since been detected in numerous tissues, including the epithelial cells at various barrier sites ${ }^{(31)}$ The presence of CYP27B1 in extrarenal tissues has been proposed as a mechanism by which vitamin $\mathrm{D}$ may exert a host of protective actions within these tissues ${ }^{(32)}$. In the present experiment, the mRNA expression of CYP27B1 in the mid-jejunum was also increased after the PRV challenge. This result is in agreement with that reported by Hansdottir et $a l^{(32)}$. Hansdottir et $a l^{(32)}$ reported that polyinosinic-polycytidylic acid-treated primary airway epithelial cells have a significantly higher expression of CYP27B1 mRNA than untreated cells. However, dietary supplementation with 5000 IU vitamin D in pigs challenged with PRV improved challenge-induced symptoms, as indicated by attenuated growth depression, decreased diarrhoea incidence, increased serum $1,25(\mathrm{OH})_{2} \mathrm{D} 3$ concentration and decreased intestinal damage. These results indicate that vitamin $\mathrm{D}$ has protective effects in pigs under PRV challenge conditions. In addition, the protective effects of vitamin $\mathrm{D}$ were also observed in vitro. Khoo et $a l .{ }^{(33)}$ reported that vitamin $\mathrm{D}$ down-regulates the proinflammatory cytokine response to Mycobacterium tuberculosis through pattern recognition receptors.

Mammalian innate immune responses to viral infections are critically dependent on a successful type I IFN response ${ }^{(9,34,35)}$. Type I IFN mediates antiviral activity by triggering the expression of IFN-stimulated genes, the products of which have diverse antiviral activities. RIG-I signalling is the main arm of innate immunity under double-stranded RNA virus challenge conditions ${ }^{(16,17,36)}$. In the present experiment, the mRNA expression of RIG-I,IPS-1,IFN- $\beta$ and $I S G_{15}$ in the intestine was up-regulated to various degrees after the PRV challenge. This is in close agreement with previous reports that RIG-I signalling through IPS-1 is required for the activation of IFN- $\beta$ production by rotavirus-infected intestinal epithelial cells or mouse embryonic fibroblast cells and has a crucial role in the determination of the magnitude of rotavirus replication in the intestinal epithelium ${ }^{(16,17)}$. To our 
knowledge, the present study is the first to demonstrate that the activation of the antiviral response by rotavirus is dependent on the RIG-I signalling pathway in vivo.

We also found that vitamin $\mathrm{D}$ is closely related to the RIG-I signalling pathway, which mediates innate immunity responses. The detection of pathogen-associated molecular patterns by pattern recognition receptors is critical for the initiation and coordination of immune responses against viral infections. To date, only the TLR have been reported to be associated with the immunological activities of vitamin $D$. A previous study has shown that the activation of TLR2/ TLR1 on human macrophages increases the synthesis of $1,25(\mathrm{OH})_{2} \mathrm{D} 3$ by these cells. This consequently induces an increase in the concentration of the antimicrobial peptide cathelicidin, leading to the destruction of intracellular M. tuberculosis ${ }^{(37)}$. Ovsyannikova et al. ${ }^{(38)}$ reported the first evidence that polymorphisms in vitamin $\mathrm{D}$ receptor and $R I G-I$ genes influence rubella vaccine-induced cellular immunity. In the present experiment, dietary supplementation with $5000 \mathrm{IU}$ vitamin D increased the mRNA expression of $R I G-I$, $I P S-1, I F N-\beta$ and $I S G_{15}$. Thus, the present results also suggest that the immunomodulatory effects of $1,25(\mathrm{OH})_{2} \mathrm{D} 3$ on rotavirus arise from its influence on the RIG-I signalling pathway. However, how vitamin D interacts with the RIG-I signalling pathway is not known still and requires further study.

In conclusion, dietary vitamin D supplementation attenuated weight gain and feed intake reduction caused by the PRV challenge. It is possible that the protective effects of vitamin D in pigs challenged with PRV are associated with the activation of the RIG-I signalling pathway through the up-regulation of $R I G-I, \quad I P S-I, \quad I F N-\beta$ and $I S G_{15}$ mRNA expression.

\section{Acknowledgements}

The authors thank Dr Jun Jiang for his assistance in the preparation of the figures. The present study was supported by the Program for ChangJiang Scholars and Innovative Research Team in the University, Ministry of Education of China (IRTO555), and the earmarked fund for the China Agriculture Research System (CARS-36) to D. C.

The authors' contributions are as follows: Y. Z. conducted the animal trial, performed the RT-PCR and ELISA experiments, and wrote the manuscript; B. Y. and X. M. contributed to the design of the study; J. H. and Z. H. assisted with the preparation of the manuscript; P. Z. and J. Y. assisted with all data analyses; G. H. and X. L. assisted with the animal trial.

None of the authors has any conflicts of interest to declare.

\section{References}

1. Kawai T \& Akira S (2009) The roles of TLRs, RLRs and NLRs in pathogen recognition. Int Immunol 21, 317-337.

2. Palm NW \& Medzhitov R (2009) Pattern recognition receptors and control of adaptive immunity. Immunol Rev 227, 221-233.

3. Takeuchi O \& Akira S (2009) Innate immunity to virus infection. Immunol Rev 227, 75-86.
4. Yoneyama M, Kikuchi M, Natsukawa T, et al. (2004) The RNA helicase RIG-I has an essential function in double-stranded RNA-induced innate antiviral responses. Nat Immunol 5, 730-737.

5. Yoneyama M, Kikuchi M, Matsumoto K, et al. (2005) Shared and unique functions of the DExD/H-box helicases RIG-I, MDA5, and LGP2 in antiviral innate immunity. I Immunol 175, 2851-2858.

6. Kawai T, Takahashi K, Sato S, et al. (2005) IPS-1, an adaptor triggering RIG-I- and Mda5-mediated type I interferon induction. Nat Immunol 6, 981-988.

7. Seth RB, Sun L, Ea CK, et al. (2005) Identification and characterization of MAVS, a mitochondrial antiviral signaling protein that activates NF-кB and IRF 3. Cell 122, 669-682.

8. Xu LG, Wang YY, Han KJ, et al. (2005) VISA is an adapter protein required for virus-triggered IFN-beta signaling. Mol Cell 19, 727-740.

9. Randall RE \& Goodbourn S (2008) Interferons and viruses: an interplay between induction, signalling, antiviral responses and virus countermeasures. J Gen Virol 89, 1-47.

10. Prosser DE \& Jones G (2004) Enzymes involved in the activation and inactivation of vitamin D. Trends Biochem Sci 29, 664-673.

11. Urashima M, Segawa T, Okazaki M, et al. (2010) Randomized trial of vitamin D supplementation to prevent seasonal influenza A in schoolchildren. Am J Clin Nutr 91, 1255-1260.

12. Hansdottir S, Monick MM, Lovan N, et al. (2010) Vitamin D decreases respiratory syncytial virus induction of NFkappaB-linked chemokines and cytokines in airway epithelium while maintaining the antiviral state. J Immunol 184, 965-974.

13. Teichmann J, Stephan E, Lange U, et al. (2003) Osteopenia in HIV-infected women prior to highly active antiretroviral therapy. J Infect 46, 221-227.

14. Gal-Tanamy M, Bachmetov L, Ravid A, et al. (2011) Vitamin D: an innate antiviral agent suppressing hepatitis C virus in human hepatocytes. Hepatology 54, 1570-1579.

15. Donelli G \& Superti F (1994) The rotavirus genus. Comp Immunol Microbiol Infect Dis 17, 305-320.

16. Broquet AH, Hirata Y, McAllister CS, et al. (2011) RIG-I/ MDA5/MAVS are required to signal a protective IFN response in rotavirus-infected intestinal epithelium. I Immunol 186, $1618-1626$.

17. Sen A, Pruijssers AJ, Dermody TS, et al. (2011) The early interferon response to rotavirus is regulated by PKR and depends on MAVS/IPS-1, RIG-I, MDA-5, and IRF3. $J$ Virol 85, 3717-3732.

18. National Research Council (NRC) (1998) Nutrient Requirements of Swine, 10th ed. Washington, DC: National Academic Press.

19. Liu F, Li G, Wen K, et al. (2010) Porcine small intestinal epithelial cell line (IPEC-J2) of rotavirus infection as a new model for the study of innate immune responses to rotaviruses and probiotics. Viral Immunol 23, 135-149.

20. Botic T, Klingberg TD, Weingartl H, et al. (2007) A novel eukaryotic cell culture model to study antiviral activity of potential probiotic bacteria. Int J Food Microbiol 115 , $227-234$.

21. Spearman C (1908) The method of right and wrong cases (constant stimuli) without Gauss's formulae. Br J Psychol 2 , $227-242$.

22. Graham DY, Dufour GR \& Estes MK (1987) Minimal infective dose of rotavirus. Arch Virol 92, 261-271.

23. Wang W, Gu W, Tang X, et al. (2009) Molecular cloning, tissue distribution and ontogenetic expression of the amino acid transporter $b^{(0,+)}$ cDNA in the small intestine of Tibetan 
suckling piglets. Comp Biochem Physiol B Biochem Mol Biol 154, 157-164.

24. Cukor G \& Blacklow NR (1984) Human viral gastroenteritis. Microbiol Rev 48, 157-179.

25. Barnett B (1983) Viral gastroenteritis. Med Clin North Am 67, $1031-1058$

26. Boshuizen JA, Reimerink JH, Korteland-van MA, et al. (2003) Changes in small intestinal homeostasis, morphology, and gene expression during rotavirus infection of infant mice. J Virol 77, 13005-13016.

27. Katyal R, Rana SV, Vaiphei K, et al. (1999) Effect of rotavirus infection on small gut pathophysiology in a mouse model. J Gastroenterol Hepatol 14, 779-784.

28. Osborne MP, Haddon SJ, Spencer AJ, et al. (1988) An electron microscopic investigation of time-related changes in the intestine of neonatal mice infected with murine rotavirus. $J$ Pediatr Gastroenterol Nutr 7, 236-248.

29. Jiang B, Snipes-Magaldi L, Dennehy P, et al. (2003) Cytokines as mediators for or effectors against rotavirus disease in children. Clin Diagn Lab Immunol 10, 995-1001.

30. Kamen DL \& Tangpricha V (2010) Vitamin D and molecular actions on the immune system: modulation of innate and autoimmunity. J Mol Med 88, 441-450.

31. Bell NH (1998) Renal and nonrenal 25-hydroxyvitamin D1alpha-hydroxylases and their clinical significance. J Bone Miner Res 13, 350-353.
32. Hansdottir S, Monick MM, Hinde SL, et al. (2008) Respiratory epithelial cells convert inactive vitamin D to its active form: potential effects on host defense. J Immunol 181, 7090-7099.

33. Khoo AL, Chai LY, Koenen HJ, et al. (2011) Vitamin D(3) down-regulates proinflammatory cytokine response to Mycobacterium tuberculosis through pattern recognition receptors while inducing protective cathelicidin production. Cytokine 55, 294-300.

34. Smith PL, Lombardi G \& Foster GR (2005) Type I interferons and the innate immune response - more than just antiviral cytokines. Mol Immunol 42, 869-877.

35. Hiscott J (2007) Triggering the innate antiviral response through IRF-3 activation. J Biol Chem 282, 15325-15329.

36. Hirata Y, Broquet AH, Menchen L, et al. (2007) Activation of innate immune defense mechanisms by signaling through RIG-I/IPS-1 in intestinal epithelial cells. J Immunol 179, $5425-5432$.

37. Liu PT, Stenger S, Li H, et al. (2006) Toll-like receptor triggering of a vitamin D-mediated human antimicrobial response. Science 311, 1770-1773.

38. Ovsyannikova IG, Dhiman N, Haralambieva IH, et al. (2010) Rubella vaccine-induced cellular immunity: evidence of associations with polymorphisms in the Toll-like, vitamin A and $\mathrm{D}$ receptors, and innate immune response genes. Hum Genet 127, 207-221. 